\title{
非線形分散波方程式における異なる 砕波減衰モデルによる流れ場の推定特性
}

\author{
田島 芳満 $1 \cdot$ Siddique MOHSIN 2 \\ 1正会員 東京大学大学院 工学系研究科准教授（†113-8656 東京都文京区本郷7-3-1） \\ E-mail:yoshitaji@coastal.t.u-tokyo.ac.jp \\ ${ }^{2}$ Lecturer, University of Engineering and Technology, Lahore, Pakistan \\ E-mail:yourmohsin@hotmail.com
}

\begin{abstract}
本論文では, 数值波動モデルにおける砕波帯周辺での流れ場の再現特性を卓越的に規定する砕波減衰モ デルに着目し，異なるモデルによる流れ場再現結果の比較を通じてその特性を把握することを目的とする. 波動モデルには修正ブシネスク方程式を用い，砕波減衰モデルには，一般的に良く用いられる抵抗型およ び拡散型の砕波減衰項に加え, 砕波する波峰の前面に形成される大規模渦へのエネルギ一輸送をモデル化 したSurface Rollerモデルを導入し，それぞれ波高や底面軌道流速，さらには波谷下における戻り流を比較 した. その結果，いずれのモデルも波高や平均水位の変化を妥当に再現するものの，軌道流速の非対称波 形や戻り流れの再現性はモデルにより大きく異なり，大規模渦へのエネルギー輸送と質量輸送を考慮する ことにより再現性が向上することが分かった。
\end{abstract}

Key Words : surf zone, undertow, breaking wave model, surface roller,near-bottom orbital current

\section{1. はじめに}

修正ブシネスク方程式に代表されるように，沿岸域に おける波の非線形性や分散特性を考慮した時間発展型非 線形分散波モデルの発展は目覚ましく，砕波帯内を含む 沿岸域の波高や波向の分布については実用上十分な精度 で予測することが可能である．しかしながら，波浪の伝 搬, 変形に伴う二次的な現象である沿岸海浜流や戻り流 れ，また底面付近における非対称な軌道流速波形の予測 精度については未だ課題が残されていると考えられる. 例えばJohnson et al. ${ }^{1}{ }^{1}$ は位相平均型の海浜流モデルや修正 ブシネスク方程式を開口部を有する潜堤周辺の波・流れ 場の再現に適用し, 海浜流場や砕波に伴う setupについて は修正ブシネスク方程式よりも位相平均型モデルの方が 良い再現性が得られたことを報告している，また，田島 ら²は修正ブシネスク方程式を，また田島 ${ }^{3)}$ は位相平均型 準三次元海浜流モデルをそれぞれ潜堤背後に発達寸る循 環海浜流場の再現計算に適用し，ブシネスク方程式では, 砕波モデルによって循環流場の再現性が大きく異なるこ と, また, 最も良い再現性を示した異方拡散型の砕波減 衰項を用いても計算された海浜流場は過小評価傾向とな ること，また潜堤上での砕波に伴う岸向質量輸送が，循
環流場の形成に大きく寄与しており，位相平均型モデル においては，準三次元モデルに基づき砕波やその全面に 形成されるSurface Rollerに伴う岸向質量輸送をモデルに 組み込むことによって妥当な再現性が得られることなど を論じている.

これらの先行研究を受け本研究では, 砕波帯周辺にお ける流れ場再現特性の卓越的な支配因子であると考えら れる砕波減衰モデルに着目し, 異なる砕波減衰モデルに よる流れ場の計算結果と実測結果との比較・検証するこ とにより, 時間発展型の平面波動モデルにおける砕波帯 内流れ場の予測精度向上に資する知見を得ることを目的 とする.また本研究では，砕波モデルの違いによる流れ 場への影響が現れや寸いと考えられる, 潜堤周辺の波・ 流れ場特性を詳細に把握するため，室内実験も新たに実 施した.

\section{2. 実験の概要}

実験ケースの概要を表-1に示寸. 本研究では砕波形態 や潜堤による波・流れ場の違いを定量的に捉えることに 焦点をあてて，実験条件を選定した。ここで $h_{S B}$ は潜堤 
設置時における天端水深である.

表-1実験条件

\begin{tabular}{|c|c|c|c|c|c|}
\hline case & 潜堤 & $H_{0}(\mathrm{~cm})$ & $T(\mathrm{~s})$ & $h_{S B}(\mathrm{~m})$ & 砕波形態 \\
\hline $1 \mathrm{~A}$ & 有 & \multirow{2}{*}{4.6} & \multirow{2}{*}{1.25} & 2.6 & \multirow{2}{*}{ Spilling } \\
\hline $1 \mathrm{~B}$ & $\begin{array}{l}\text { 無 } \\
\end{array}$ & & & - & \\
\hline $2 \mathrm{~A}$ & 有 & \multirow{2}{*}{2.6} & \multirow{2}{*}{2.0} & 3.5 & \multirow{2}{*}{ Plunging } \\
\hline $2 \mathrm{~B}$ & 無 & & & - & \\
\hline
\end{tabular}

図-1には，実験の概要を示す，砕波帯を含む複数地点 において容量式波高計を用いて時々刻々の水位変動を計 測し，潜堤周辺から汀線付近までの砕波帯内を中心に複 数の水深において超音波ドップラー流速計を用いて時々 刻々の流れ場を計測した．流速計測における鉛直方向の 計測間隔は砕波点で3mm，それ以外で5mmとした。それ ぞれの地点において，流速は10波分計測され，計測值を 平均することにより，各点における平均流速を算出した 図-2には，表-1に示した各実験ケースに対する，平均水 平流速成分の鉛直断面分布を示している. 図より，水平 流速の鉛直断面分布は，潜堤を設置するか否かによりそ の特性が大きく異なることが読み取れる.

\section{3. 数值モデルの概要}

本研究では, 非線形分散波の浅水変形に次式で示され るMadsen and Sorensen ${ }^{4}$ の弱非線形性修正ブシネスク方程
式を用いた。

$$
\eta_{t}+P_{x}=0
$$

$$
\begin{aligned}
& P_{t}+\left(P^{2} / d\right)_{x}+g d \eta_{x} \\
& -B g h^{3} \eta_{x x x}-(B+1 / 3) h^{2} P_{x x t} \\
& -2 B g h^{2} h_{x} \eta_{x x}-1 / 3 h h_{x} P_{x t}+F_{b r}=0
\end{aligned}
$$

ここで， $\eta$ および $P$ は時々刻々の水位および線流量, $h$ は静水深, $d=h+\eta$ は時々刻々の全水深, $g$ は重力加速度, $F_{b r}$ は後述する任意の砕波減衰項である。 また分散項の 係数 $\mathrm{B}$ は $\mathrm{B}=1 / 15$ とし，下付き文字 $x$ および $t$ は水平方向お よび時間方向の偏微分をそれぞれ表す．以下本研究で導 入した砕波減衰項を整理する。

\section{(1) 抵抗型砕波減衰項}

Watanabe and Dibajnia ${ }^{5)}$ は，運動方程式中における砕波に 伴う減衰抵抗が，時々刻々の線流量に比例するとする仮 定に基づく次式で砕波減衰項を定義した。

$$
F_{b r}=-f_{D} P
$$

ここで抵抗係数は基礎方程式を位相平均して導いたエ ネルギー平衡方程式中のエネルギー減衰率が，既往のモ デルと一致するように導出した次式で定義し,

$$
f_{D}=\alpha_{D} \tan \beta \sqrt{\frac{g}{\bar{d}} \frac{\gamma-\gamma_{r}}{\gamma_{s}-\gamma_{r}}}
$$

$\alpha_{D}=2.5$ は理論的に導かれる定数， $\tan \beta$ は水底勾配， $\gamma$ は

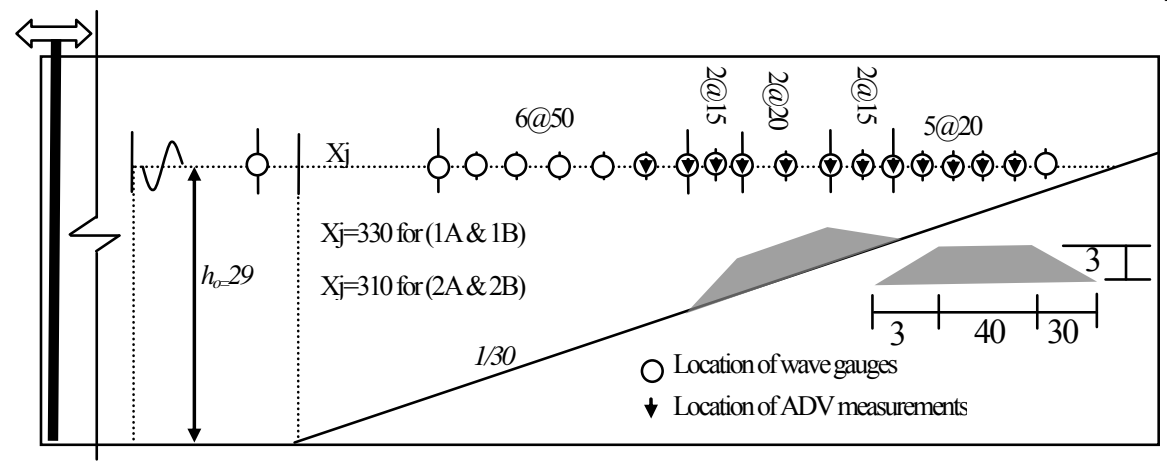

図-1＼cjkstart実験概要図
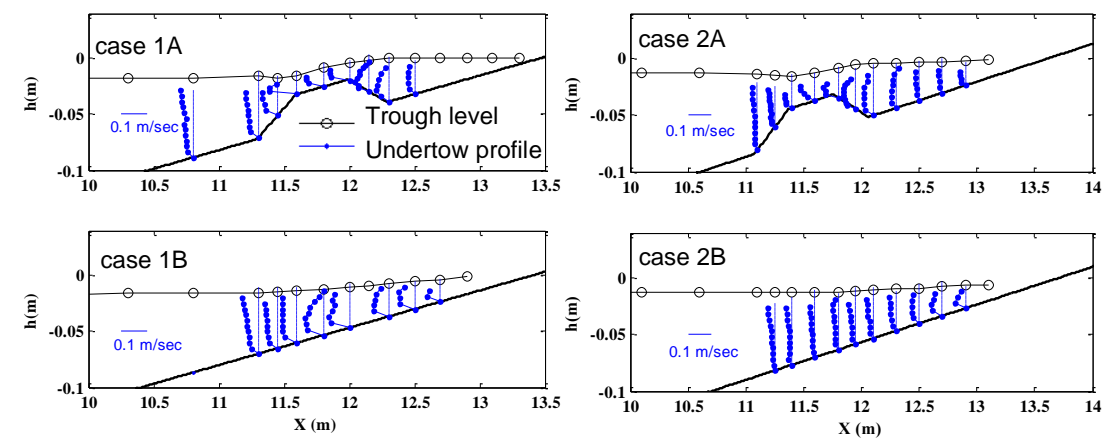

図-2 各実験ケースにおける平均水平流速成分の鉛直断面分布 
波高水深比， $\bar{d}$ は平均水深， $\gamma_{\mathrm{s}}$ および $\gamma_{r}$ は砕波した波が それぞれ一様水深上および一様勾配斜面上を伝搬すると きに漸近する $\gamma$ の值である ${ }^{0}$. 砕波減衰項の導入開始地 点を決定するための, 砕波限界点の指標には流速波速比 を用いた》。

\section{(2) 拡散型砕波減衰項}

拡散型の砕波減衰項は一般的に次式で表される.

$$
F_{b r}=-\left(\varepsilon_{B} P_{x}\right)_{x}
$$

拡散係数 $\varepsilon_{B}$ については, 前述の抵抗型モデルと同様に 拡散型減衰項を導入した運動方程式から導出したエネル ギー平衡方程式において表現されるエネルギー減衰率が 既往の砕波減衰モデルと一致するように決定するモデル 8)や，砕波により波エネルギーの一部が乱れエネルギー へと供給されると仮定して, 乱れ場の運動方程式を計算 し，相当する渦動粘性係数 $v_{t}$ を拡散係数として与えるモ デル9などが提案されており，本研究では後者を用いた すなわち, 乱れに伴う運動エネルギー $k$ の時間変化を次 の-方程式を用いて算定し,

$k_{t}+u_{s} \frac{\partial k}{\partial x}=\frac{v_{t}}{\sigma_{k}} \frac{\partial^{2} k}{\partial x^{2}}+B_{r} v_{t}\left[\frac{\partial^{2} h u}{\partial x^{2}}+\eta \frac{\partial^{2} u}{\partial x^{2}}\right]^{2}-C_{D} \frac{k^{3 / 2}}{l_{t}}(6)$

$k$ に相応する渦動粘性係数 $v_{T}$ を次式で算定した.

$$
v_{t}=\sqrt{k} l_{t}
$$

ここで $u_{s}$ は表層での水平流速, $u$ は断面平均流速, $C_{D}(=0.08)$ および $\sigma_{k}(=1.0)$ はそれぞれ減衰, 拡散係数である。 式(6)の右辺第二項は砕波に伴うエネルギー供給率を表 し, 係数 $B_{r}$ は砕波指標に基づき砕波条件では1, 非砕波 条件では0となる. 乱れ運動の長さスケールを表すには, 先行研究にならい沖波波高として与えた.

\section{(3) Surface Rollerモデル}

Svendsen ${ }^{10}$ は砕波前面に形成される大規模渦(Surface Roller, 以下SR)を導入し, 砕波帯内で増大寸る戻り流れ の再現に成功した. その後Dally and Brown ${ }^{11)}$ やTajima and Madsen ${ }^{12)}$ ，田島 ${ }^{13}$ はSRの生成，消失過程をエネルギー平 衡方程式に組み込み，SRが戻り流れ流速だけでなく， 位相平均型モデルにおけるsetupや海浜流場の再現精度の 向上にも寄与することを示している.

またSchäffer, et al. ${ }^{14}$ は時間発展型の非線形分散波モデ ルにおける運動方程式中にSRによる余剩な運動量フラ ックスとして次式を導入し，砕波に伴う波高減衰の再現 に成功している.

$$
F_{b r}=\frac{\partial R}{\partial x}=\frac{\partial}{\partial x}\left(\frac{\delta}{1-\delta / d}\left(c-\frac{P}{d}\right)^{2}\right)
$$

ここでc は波速， $\delta$ はSRの厚さであり，SRの中における 水粒子は波速と同じ速さで移動しているという仮定に基 づき，波動運動に対する余剩な運動量を式(8)で与えて いる.

ここでSchäffer, et $\mathrm{al}^{14)}$ はSRの厚さ $\delta$ を時々刻々の空間波 形から直接算定する手法を提案しているが，これでは各 計算時間ステップ毎に空間波形を参照する必要があり, 特に部分重複波を含む複雑な波浪場への適用は困難であ る.これに対してSorensen et al. ${ }^{15}$ は，空間波形の代わりに 個々の地点における水位変動 $\eta$ の履歴を用いることによ って $\delta$ を算定する次式を提案している.

$$
\delta_{o t}=\left(\eta_{t}-c \tan \phi(t)\right) \quad \delta_{o} \geq 0
$$

ここで $\delta_{0 t}$ は $\delta$ の増加率, $\tan \phi(t)$ は次式で定義される時刻 $t$ におけるSRと波峰との境界面の勾配であり，

$\tan \phi=\tan \phi_{o}+\left(\tan \phi_{B}-\tan \phi_{o}\right) \exp \left[\ln 2\left(t-t_{o}\right) / t_{S}\right]$ (10) $\tan \phi_{0}$ はSRの生成開始時 $\left(t=t_{0}\right)$ における波峰とSRとの境界 面の勾配， $\tan \phi_{B}$ はその波峰先端周辺での最大值， $t_{s}$ はSR 波峰前面を通過するSRの時間スケールである. 数值計 算上は，波谷から波峰に向けて水位が上昇する際，その 加速度 $\eta_{t}$ が閾值 $\left(\eta_{t}>c \tan \phi_{B}\right)$ を超えてから $\delta$ が増加し，その 後減少してゼロに戻るまでの過程を式(9)を用いて計算 する.

\section{（4）戻り流れ流速の算定}

修正ブシネスク方程式では，時々刻々の線流量と水面 変動が計算されるため, 波の質量輸送に伴う戻り流れの 断面平均流速 $U_{r}$ もこれらの諸量から求めた時々刻々の断 面平均流速を数值的に時間平均することによって次式で 算定することができる.

$$
U_{r}=\overline{\left(\frac{P}{h+\eta-\delta}\right)}-\overline{\left(\frac{c \delta}{h+\eta-\delta}\right)}
$$

ここで左辺式上の barは時間平均を表し，左辺第二項は SRによる影響項であり，SRモデル以外の砕波モデルで はゼロとなる．また第二項は，断面二次元条件では岸沖 方向の正味の質量輸送量がゼロとなるため, SRによっ て波面上で岸向に輸送された質量輸送が，そのまま沖向 に戻されることを仮定して定式化されている.

\section{4.＼cjkstart計算結果および実験結果の比較}

以上の異なる砕波モデルを導入した修正ブシネスク方 程式を本研究で実施した実験条件に適用し，その再現性 を比較・検証した．また岸側の遡上境界での計算方法に ついては, Madsen et al. ${ }^{16}$ と同様の透水層モデルを用いた. 潜堤にも透水層を用いたが， Ranasinghe et al..$^{17}$ と同様に急 
激に水深が変化する潜堤天端縁部では，運動方程式中に 急拡に伴うエネルギー減衰項を強制的に付加した.

\section{（1）波高, 平均水位，および戻り流れ}

図-3に各実験条件に対寸る波高，平均水位，戻り流れ の断面平均流速の岸沖方向分布を示す．図より，波高の 岸沖方向分布については砕波モデルによる大きな違いは 見られず，いずれのモデルにおいても，砕波形態によら ず潜堤上での急激な波高減衰や，潜堤岸側での砕波の回 復(波高の安定化)を含む波高变化を良好に再現できてい る. 潜堤を設置したケースでは，砕波点の沖側において 部分重複波が形成されているが，その腹節の位置がモデ ル間でやや異なっている．砕波点の位置もモデルにより ややずれていることから，部分重複波を形成する反射波 は急激な砕波による影響を受けていると推察される．抵
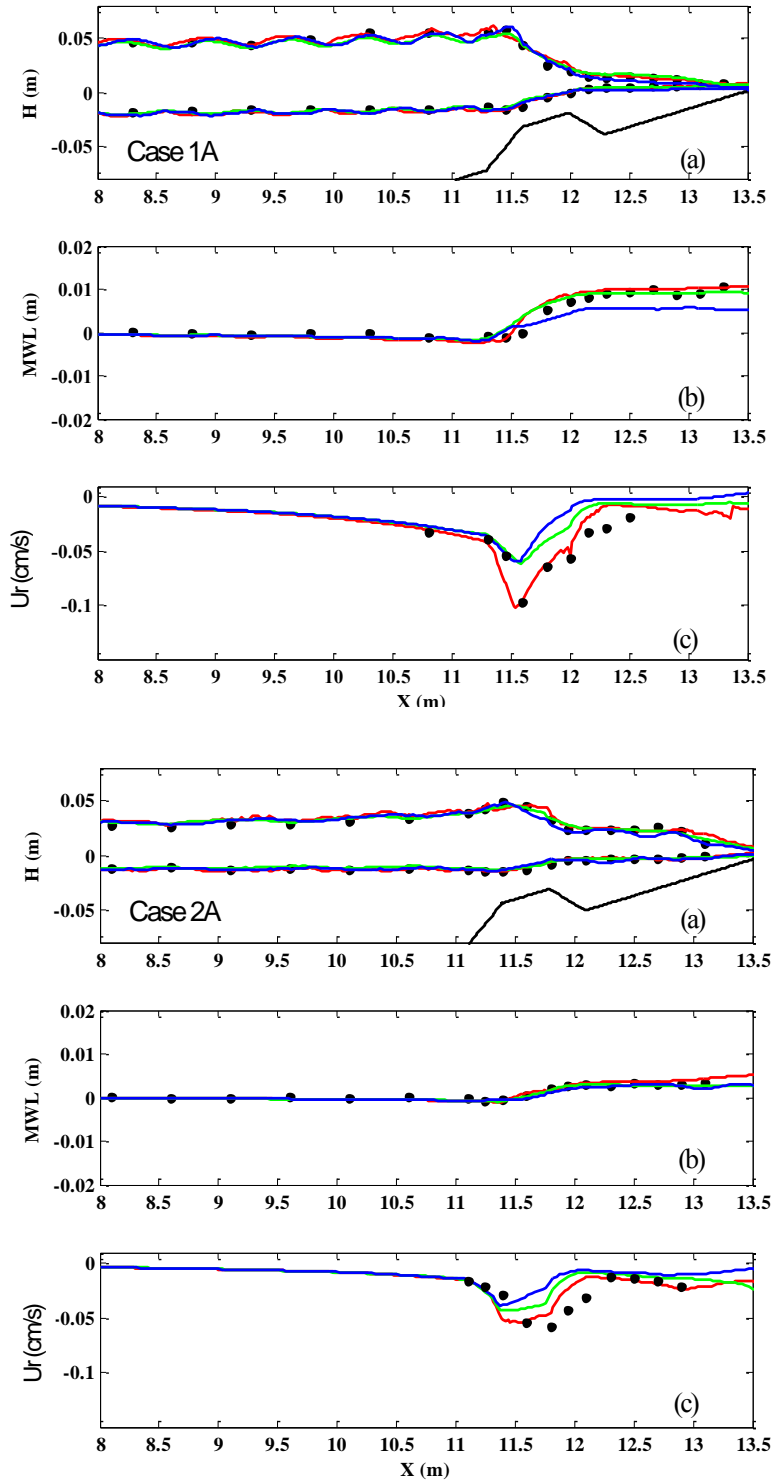

抗型モデルでは，砕波点で急激な抵抗が生じるためより 大きな反射波が形成されると予想されたが，部分重複波 による水位の変動幅はモデル間での顕著な違いは見られ ず，いずれのモデルにおいても同等の反射波が形成され たものと考えられる.

次に平均水位の岸沖方向分布に着目する. SRモデル および拡散型モデルでは，ほぼ同等の計算結果を与え実 測值を妥当に再現できているのに対して，抵抗型モデル では砕波帯内における平均水位の上昇量が過小評価され ており，田島ら ${ }^{2)}$ に同様の傾向が見られた．後述する 戻り流れや流速波形の比較において抵抗型モデルでは, 流速值が過小評価される傾向があり，砕波帯内における 運動エネルギーが他のモデルに比べて小さくなっている ことなどが原因の一つとして推察されるが，その場合は 砕波点近傍において他のモデルよりも急激な運動量の低
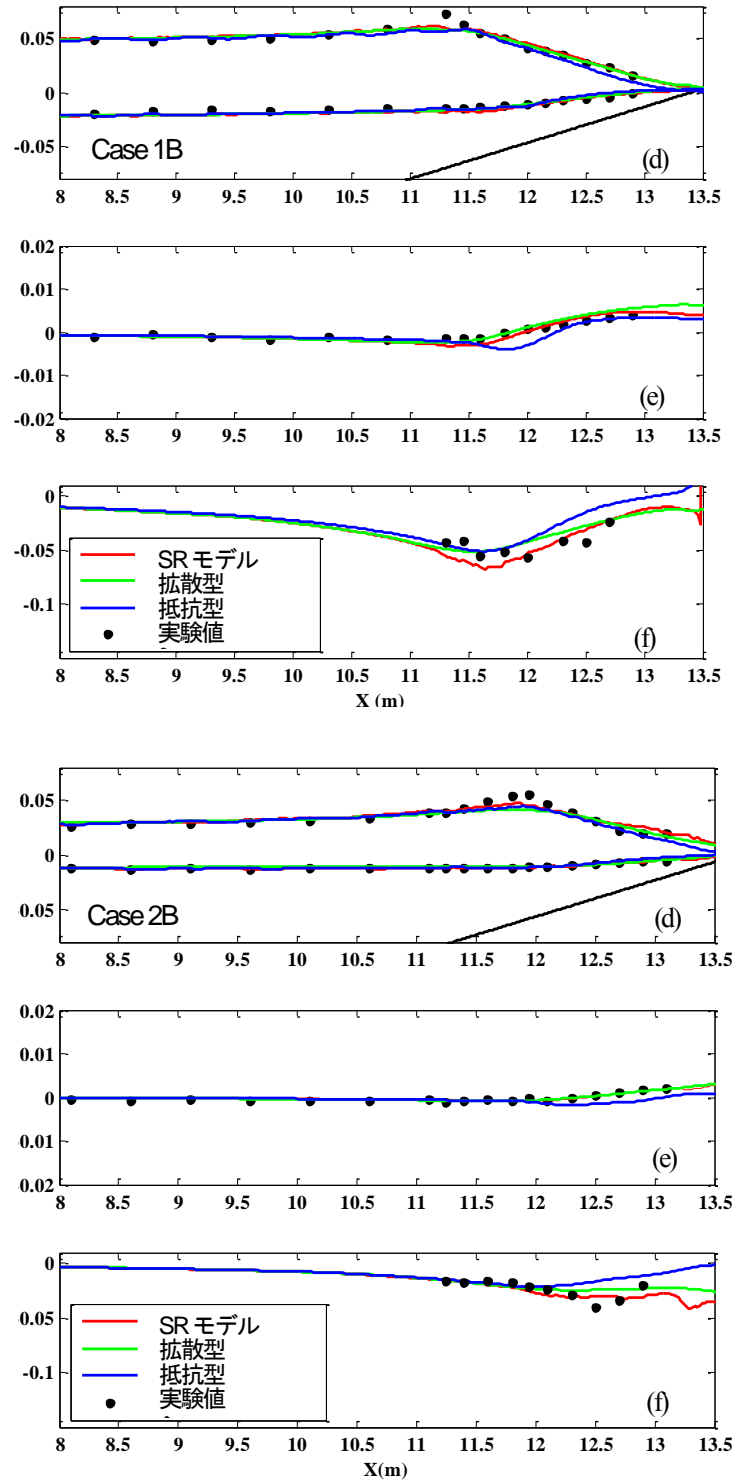

図-3 波高，平均水位，戻り流れ断面平均流速 $U_{r}$ の岸沖方向分布の比較(Case 1A, 1B, 2A, 2B) (実線 : 計算結果(赤 : SR モデル，緑 : 拡散型モデル，青 : 抵抗型モデル), 黒点 : 実験值) 

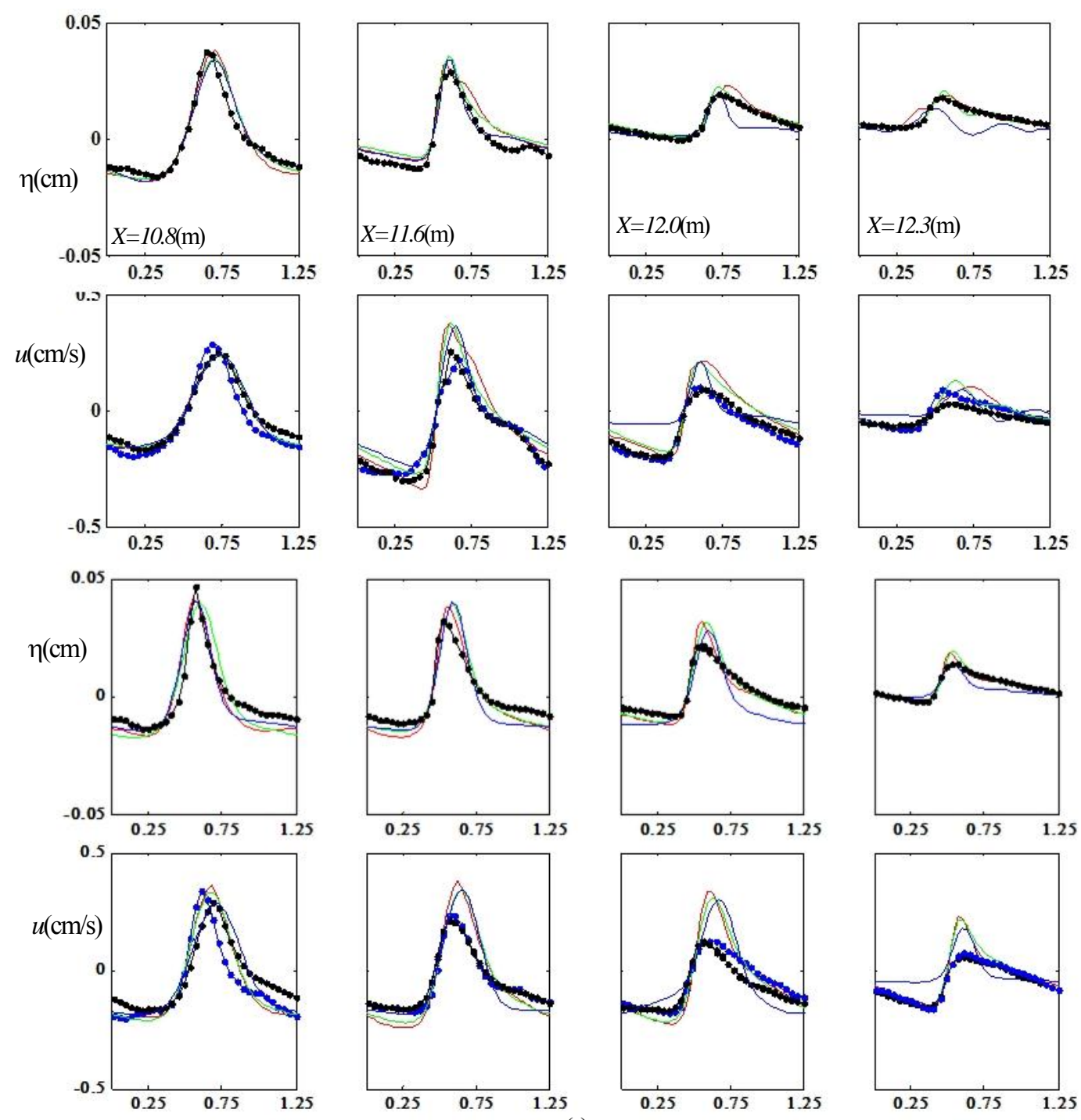

$t(\mathrm{~s})$

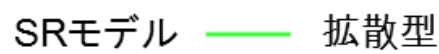

抵抗型

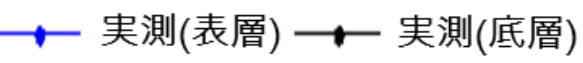

図-4 水位および流速波形の比較(上段 : Case 1A，下段：Case 1B)

下に伴う急激な水位上昇があるはずであり，結果に矛盾 が生じる.今後さらに詳細を分析する必要がある。

最後に戻り流れの断面平均流速に着目すると, SRに よる質量輸送量を考慮したSRモデルでは，潜堤設置時 も含め，砕波帯内における戻り流れ流速の増大を妥当に 再現できているのに対し，他の2つのモデルでは過小評 価となった．特に抵抗型モデルでは，以下の比較でも考 察するように波高が同程度でも流速が過小評価される傾 向があり，結果として戻り流れ流速についても抵抗型が 最も過小評価した。

\section{(2) 底面軌道流速波形}

最後に図-4に時々刻々の水面波形と底面軌道流速波形 について, case 1Aおよび1Bの結果を実測值と比較した. case 2 にいては図示していないが, case 1 とほぼ同等の 傾向が見られた。また実測值では，参考のために表層お よび底層における水平流速の波形を一緒に図示した。図
より，抵抗型モデルでは水位や流速が位相に関係なく低 減させるため，特に波峰以外の位相における流速值や水 位を過大に減衰させ，結果として流速值および水位を過 小評価してしまっていることがわかる. これに対して拡 散型モデルやSRモデルでは，運動方程式中での減衰が 波峰周辺に集中寸る特性があるため, このような問題が 生じにくく，結果として波谷周辺での再現性が比較的良 い. SRモデルの波形に着目すると，本研究で用いたSR モデルでは，波峰前面(岸側)のみに生成するSRの運動に 波エネルギーの一部が供給されるため, 運動方程式中に おける波エネルギーの減衰は，波峰前面の位相でのみ生 じることになる. SRの波形は波峰の沖側(図中の波峰ピ 一クの右側)においてやや過大評価される傾向がみられ， このことは，砕波に伴うエネルギー減衰はSRへのエネ ルギ一供給だけではなく, 波峰沖側においても乱れ等に 伴う何らかのエネルギー減衰が生じていることを示唆し ていると考えられる. また，特に砕波帯内における流速 
波形のピークは実測值に比べて過大となる傾向が見られ た.これは，本研究で用いた修正ブシネスク方程式が強 非線形性を考慮できていないことが理由の一つとして考 えられるが，実測值における表層と底層の流速值の違い はそれほど大きくないことや，両者の位相に違いが見ら れることなどを勘案すると, ブシネスク方程式では評価 できていない，底面境界層を含む戻り流れの鉛直分布に よる影響なども考えられる.

\section{5. おわりに}

修正ブシネスク方程式に基づき，異なる砕波モデルに よる波・流れ場の再現特性を比較検証した，位相平均型 モデルと同様にSRモデルでは，砕波帯内における戻り 流れ流速の増大を妥当に再現することができたが，軌道 流速波形の再現については未だ課題が残されている.

謝辞：本研究の成果の一部は科研費(若手研究(A), 課題 番号23686070, 研究代表者: 田島芳満)の助成を受けまし た. 記して深甚なる謝意を表します.

\section{参考文献}

1) Johnson, H. K., Karambas, T. V. and Avgeris, I. : Modelling of waves and currents around submerged breakwaters, Coastal Engineering, 52 (10-11), pp. 949-969, 2005.

2) 田島芳満, 佐藤愼司, 鈴木淳也, 下園武範, 磯部雅 彦：潜堤周辺の砕波・乱流特性を考慮した海浜流場 予測モデルに関する一考察, 海岸工学論文集, 第 53 巻, pp.106-110, 2006 .

3）田島芳満：波および Surface Roller による質量輸送を 考慮した準三次元海浜流モデルの構築, 土木学会論 文集 B2(海岸工学), pp.106-110, 2010.

4) Madsen, P. A., Sørensen, O. R., Schäffer, H. A. : Surf zone dynamics simulated by a Boussinesq type model. Part I. Model description and cross-shore motion of regular waves. Coastal Engineering. 32 (4), pp. 255-287, 1997.

5) Watanabe, A. and Dibajnia, M. : A Numerical Model of Wave Deformation in Surf Zone. Proceedings of the 21st
Int. Conf. on Coast. Eng., pp. 578-587, ASCE, 1988.

6)田島芳満, O. S. Madsen : Surface Rollerによる影響を 考慮した戻り流れの鉛直分布のモデリング, 土木学 会論文集 No.803/II-73，pp.133-144， 2005.

7) Tajima, Y. and O.S. Madsen : Shoaling, breaking, and broken wave characteristics, Proc. 28th Int. Conf. on Coast. Eng., pp.222-234, 2002.

8) 佐藤愼司・鈴木秀典：砕波帯における底面流速変動 波形の評価法，海工論文集，第 37 巻，pp.51-55, 1990.

9) Nwogu, O.G.: Numerical prediction of breaking waves and currents with a Boussinesq model, 25th ICCE, pp.48074820, 1996.

10) Svendsen, I.A. : Wave heights and set-up in a surf zone. Coastal Eng. 8 (4), pp. 303-329, 1984.

11) Dally, W. R. and C. A. Brown : A modeling investigation of the breaking wave roller with application to cross-shore currents, JGR., 100(C12), pp.24873- 24883, 1995.

12) Tajima, Y., and O.S. Madsen : Modeling near-shore waves and surface rollers, 2nd Int. Conf. on Asian and Pacific Coasts, CD-ROM published by World Scientific, 2003.

13）田島芳満 : 波および Surface Roller による質量輸送を 考慮した準三次元海浜流モデルの構築, 土木学会論 文集 B2(海岸工学), pp.106-110，2010.

14) Schäffer, H. A.; Madsen, P. A.; Deigaard, R. : A Boussinesq model for waves breaking in shallow water. In: Coastal Engineering. 20 (3-4), pp. 185-202, 1993.

15) Sorensen, O.R., Schaffer, H.A., Sorensen, L.S. : Boussinesq type modelling using an unstructured finite element technique. Coastal Eng. 50, 181-198, 2004.

16) Madsen, P. A., Sørensen, O. R., Schäffer, H. A. : Surf zone dynamics simulated by a Boussinesq type model. Part I. Model description and cross-shore motion of regular waves. Coastal Engineering. 32 (4), pp. 255-287, 1997.

17) Ranasinghe, R. S., Sato, S., Tajima, Y.: Boussinesq modelling of waves and currents over submerged breakwaters. Proc. of the 5th Int. Conf. on APAC. pp. 58-64, 2009.

\section{COMPARISONS OF BREAKING WAVE MODELS IN PREDICTIONS OF CURRENT FIELD BASED ON NON-LINEAR DISPERSIVE WAVE MODEL}

\section{Yoshimitsu TAJIMA and Siddique MOHSIN}

This paper focuses on difference of breaking wave models especially in terms of their different predictive skills of the current field around the surf zone. Widely-used modified Boussinesq equations were applied to the newly conducted experimental conditions with different breaking wave models, i.e., dispersion type, friction type and surface roller-type models. Predicted osscilating current velocity and depthaveraged undertow velocity were compared to the measured data. Comparions clearly demonstrated the advantages of the surface roller-type model in that the model succsessfully explains the increase of the undertow velocity inside the surf zone. While all the models showed excellent predictive skills of the wave heights, none of these models successfully represent the profiles of near-bottom orbital velocity. 